\title{
Analysis of Carrying Capacity of the Bored Pile Foundation in Cibubur Transpark Project
}

\author{
Resi Aseanto and Arif Sanjaya \\ Faculty of Engineering, University Mercu Buana Jakarta, Indonesia \\ Arifsanjaya06@gmail.com
}

\begin{abstract}
The foundation is a construction that continues the burden of the upper structure and passes it on to the soil below it. A bored pile foundation is now an option in working on structures in densely populated areas and tall buildings. The purpose of this study is to calculate and compare the carrying capacity of the bored pile foundation based on N-SPT data with the O 'Neil \& Reese, and Reese \& Wright methods, while the Loading test data with the interpretation of the Davisson method and the Mazurkiewicz method. The results of calculations based on N-SPT data, the average ultimate carrying capacity of the foundation with the O'neil \& Reese method of 1211.61 tons, Reese \& Wright of 1235.02 tons. While the Interpretation of Loading test method for Marzukiewicz is 1267.00 tons, Davisson is 850.40 tons, and the carrying capacity of PDA test results is 121.72 tons. From the calculation of the bearing capacity of the consecutive foundation of the smallest is the Davisson method, the O'neil \& Reese method, the PDA test method, the Reese \& Wright method, and finally the Mazurkiewicz method.
\end{abstract}

\section{Keywords}

Bored pile foundation, carrying capacity, N-SPT, Loading test.

\section{Introduction}

The foundation as a building base must be able to carry all the building loads and other expenses that are taken into account and pass them on to the deep soil. If the soil is unable to carry the foundation load or has a small carrying capacity, excessive reductions or collapse of the soil will occur. This will be damage to the structure that is above the foundation. The bearing capacity of foundation needs to be done as consideration in planning the foundation.

Based on the background and availability of data, the objectives of this study are:

1) To knowing the carrying capacity of foundation from the SPT data with the Reese \& O'neil Method and the Reese \& Wright Method.

2) To knowing the carrying capacity of foundation with interpretation the loading test using Davisson and Marzukiewicz method.

3) To Knowing the comparison of the results from calculation the carrying capacity of foundation by the SPT data, interpretation of loading test data and carrying capacity by PDA test results.

\section{Literature Review}

\subsection{General}

The foundation is the lowest part of the building that functions to support the building and all of the building's burden and carry on the building's burden, both dead load, live load and earthquake load to the ground or rocks below it.

The selection of sub-structure types, namely foundation, must consider the following matters:

- The condition of the soil

- Limitations due to the structure above it

- Limitation of the surrounding environment

- Costs and time to carry out the work 


\subsection{Bored Pile Foundation}

Bore pile is installed in the ground by drilling the soil, then reinforcing and casting concrete. This pile is usually used on stable and rigid soils, making it possible form stable hole with a drill.

Carrying capacity of bored pile is obtained from the end bearing capacity from the end pressure of the pile and the friction bearing capacity from the friction carrying capacity or the adhesion force between the bored pile and the surrounding soil. Bored piles interact with the ground to produce carrying capacity that is able to carry and provide security for the upper structure. To produce an accurate carrying capacity, an accurate soil investigation is also needed. There are two methods commonly used in determining the carrying capacity of bored piles, namely using the static method and the dynamic method.

\subsection{Carrying Capacity of Bore Pile from SPT Data}

The axial carrying capacity of bored pile foundation is the sum of the carrying capacity due to friction along the pile and the carrying capacity of the pile. In general, the ultimate bearing capacity of the pile foundation $(\mathrm{Qu})$ to the axial load can be calculated by the formula:

Where is :

$$
\mathrm{Qu}=\mathrm{Qp}+\mathrm{Qs}-\mathrm{Wp}
$$

$\mathrm{Qu}=$ the bearing capacity of the ultimit pole (tons)

$\mathrm{Qp}=$ ultimate bearing capacity of pole end (ton)

$\mathrm{Qs}=$ carrying capacity of ultimit pole blankets (tons)

$\mathrm{Wp}=$ Bored pile weight

\section{Result And Analysis}

\section{a. O'neil and Reese method}

Calculation of carrying capacity of bored pile from SPT data uses Oneil \& Reese method at point BH-1A.

Bored pile data:

$$
\begin{array}{ll}
\text { Diameter (d) } & =100 \mathrm{~cm} \\
\operatorname{Depth}(\mathrm{h}) & =22 \mathrm{~m}
\end{array}
$$

Perimeter of the pole $(p)=\pi x d$

$$
\begin{aligned}
& =3.14 \times 100 \mathrm{~cm} \\
& =314 \mathrm{~cm}
\end{aligned}
$$

$$
\begin{aligned}
& \text { Pile area }(\mathrm{A})=1 / 4 \times \pi \times \mathrm{d} 2 \\
&=1 / 4 \times 3.14 \times 1002 \mathrm{~cm} \\
&=7850 \mathrm{~cm}^{2} \\
&=0.785 \mathrm{~m}^{2} \\
& \text { Ultimate end resistance } \\
& \mathrm{N} 60=31, \sigma \mathrm{r}=100 \mathrm{Kpa} \\
& \mathrm{Fb} \quad=0.60 . \sigma \mathrm{N} 60 \\
&=0.60 .100 .31=1860 \mathrm{kPa} \\
& \mathrm{Qb}=\mathrm{Ab} . \mathrm{fb} \\
&=0.785 .1860 \mathrm{kPa}=1460.1 \mathrm{kN} \\
&=148.89 \text { tons }
\end{aligned}
$$

Ultimate friction resistance Example depth 1-3 m:

$$
\begin{aligned}
& \mathrm{N}=6, \mathrm{~N} 60=5, \mathrm{As}=6.28 \mathrm{~m} 2 \\
& \gamma \mathrm{t}=1.83 \text { tons }=17.94 \mathrm{kN} \\
& \text { po }(\text { overburden pressure })=\mathrm{D} \times \gamma \mathrm{t} \\
& \text { po } ' 1-3 \mathrm{~m}=3 \times 17.94 \mathrm{kN}=53.82 \mathrm{kN} \\
& \text { Average po '= cum } \mathrm{po}^{\prime} / 2=8.97+53.82 / 2=31.40 \mathrm{kN} / \mathrm{m}^{2} \\
& \beta=\mathrm{N} 60 / 15(1.5-0.245 \sqrt{\mathrm{z}}) \text { if } \mathrm{N} 60 \leq 15 \\
& \beta=5 / 15 .(1.5-0.245 \sqrt{ } \mathrm{1}) \\
& \beta=0.43 \\
& \mathrm{Qs}=\text { As. } \beta . \text { po } \\
& \mathrm{Qs}=6.28 \mathrm{~m}^{2} \times 0.43 \times 31.40 \mathrm{kN} / \mathrm{m}^{2} \\
& \text { Cumulative Qs BH-1A }=\mathrm{Qs}=11226.44 \mathrm{kN}=1144.78 \text { tons }
\end{aligned}
$$


$>$ Drill bore weight $(\mathrm{Wp})$

$$
\begin{aligned}
\mathrm{Wp} & =(1 / 4 . \text { П.d2) L. } \gamma \text { beton } \\
\mathrm{Wp} & =(1 / 4 . \text { П. 12). } 22.25=431.75 \mathrm{kN} \\
& =44.02 \text { tons }
\end{aligned}
$$

Ultimit bearing capacity $(\mathrm{Qu})$

$$
\begin{aligned}
\mathrm{Qu} & =\mathrm{Qb}+\mathrm{Qs}-\mathrm{Wp} \\
\mathrm{Qu} & =148.89 \text { tons }+1164.67 \text { tons }-44.02 \text { tons } \\
& =1249.65 \text { tons }
\end{aligned}
$$

\section{b. Reese \& Wright Method}

Calculation of carrying capacity of bored pile from SPT data uses Reese \& Wright method at point BH-1A.

$>$ Ultimate end resistance

$$
\begin{aligned}
\mathrm{fb} & =2 / 3 . \mathrm{N}(\mathrm{tfs}) \\
\mathrm{fb} & =2 / 3.32(\mathrm{tfs})=21.33 \mathrm{tsf}=2252.80 \mathrm{kPa} \\
\mathrm{Qb} & =\mathrm{Ab} . \mathrm{fb} \\
& =0.785 .2252 .80=1768.44 \mathrm{kN} \\
& =180.33 \text { tons }
\end{aligned}
$$

$>$ Ultimate friction resistance Example depth 1-3 m:

$$
\begin{array}{ll}
\mathrm{N} & =4 \\
\text { As } & =6.28 \mathrm{~m} 2 \\
\mathrm{fs} & =\mathrm{N} / 34(\mathrm{tfs}),(1 \mathrm{tsf}=105.6 \mathrm{kPa}) \\
\mathrm{fs} & =4 / 34 \times 105.6 \mathrm{kPa}=12.42 \mathrm{kPa} \\
\text { Qs } & =\text { As. fs } \\
\text { Qs } & =6.28 \mathrm{~m} 2 \times 12.42 \mathrm{kPa} \\
& =78.02 \mathrm{kN} \\
\text { Cumulative Qs BH-1A } & =\mathrm{Qs}=8786.98 \mathrm{kN} \\
& =896.03 \text { tons }
\end{array}
$$

Ultimit support capacity $(\mathrm{Qu})$

$$
\begin{aligned}
\mathrm{Qu} & =\mathrm{Qb}+\mathrm{Qs}-\mathrm{Wp} \\
\mathrm{Qu} & =180.33 \text { tons }+896.03 \text { tons }-44.02 \text { tons } \\
& =1032.34 \text { tons }
\end{aligned}
$$

\section{c. Interpretation data with Marzukiewich method}

The procedure for determining the ultimate load of Mazurkiewich is as follows:

1. Plotted the load curve with respect to decreases

2. Draw a line from several selected drop points to cut the curve, then draw a vertical line to cut the load axis.

3. From the intersection of each load, a 45o line is made against the next intersection line and so on.

4. Connecting the formed point to produce a straight line.

5. The intersection of the straight line with the load axis is the ultimate load.

$>$ Calculation of the KN-01 chart by the Mazurkiewicz method 


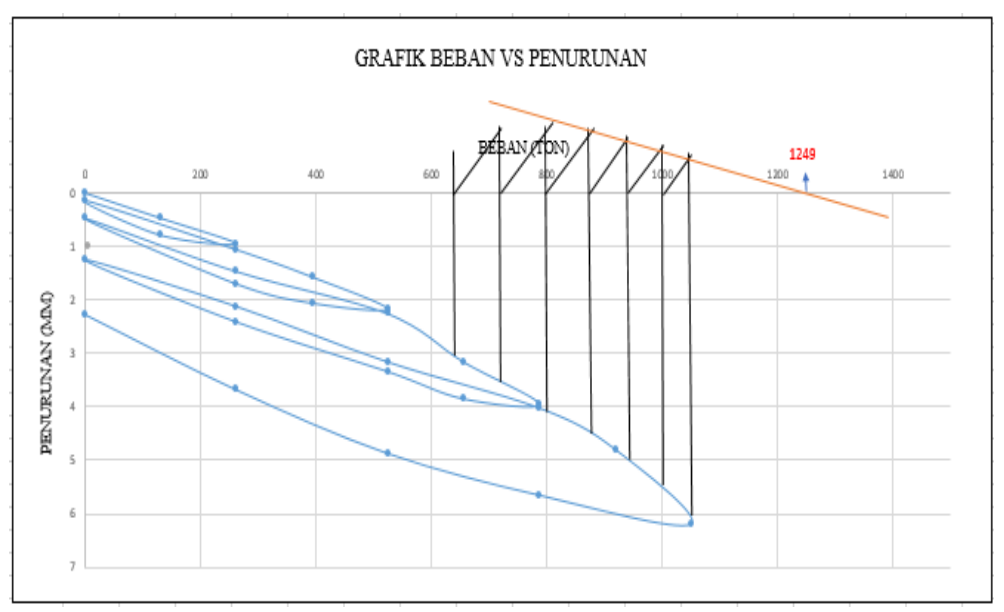

After drawing a straight line intersection with the load axis on the decrease load curve the maximum load $(\mathrm{Qu})=1249$ tons is obtained.

\section{d. Interpretation data with the Davisson Method}

Calculation of KN-01 graph by Davisson method

$$
\begin{aligned}
& \mathrm{fc} \\
& =25 \mathrm{Mpa}, \sigma \mathrm{r}=100 \\
& \mathrm{~d}=100 \mathrm{~cm}, \mathrm{dr}=30 \mathrm{~cm} \\
& \mathrm{D}=22 \mathrm{~m}, \mathrm{~A}=0.785 \mathrm{~m}^{2} \\
& \mathrm{E}=15200 \sigma \mathrm{r}(\mathrm{fc} / \sigma \mathrm{\sigma r}) 0.5 \mathrm{kN} / \mathrm{m}^{3} \\
& =15200 \times 100 \times(25000 / 100) 0.5 \\
& =24.03 \times 106 \mathrm{kN} / \mathrm{m}^{2} \\
& =24.03 \mathrm{kN} / \mathrm{mm}^{2} \\
& =0.012 \mathrm{dr}+0.1 \mathrm{~d} / \mathrm{dr}+\mathrm{QD} /(\mathrm{AE}) \\
& =0.012(300)+0.1(1000) /(300)+\mathrm{Q}(22000) /(785000 \times 24.03) \\
& =3.6+0.33+0.0011 \mathrm{Q} \\
& =3.93+0.0011 \mathrm{Q}(\text { linear line equation })
\end{aligned}
$$

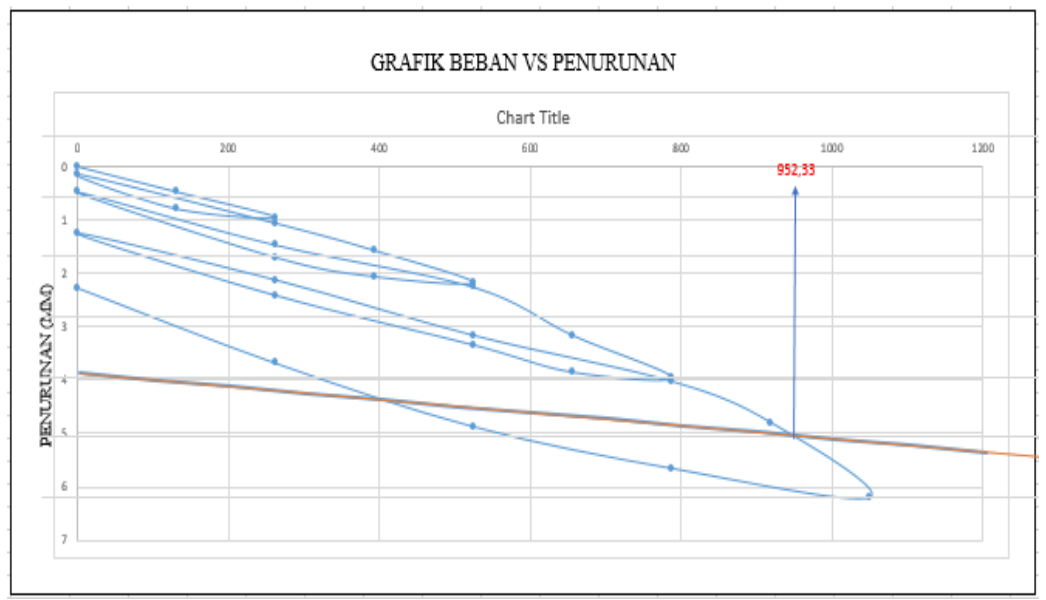

After drawing a line on the decrease load curve the maximum load $(\mathrm{Qu})=952.33$ tons is obtained. 


\section{e. Compressive Strenght}

Table 1. Qull Resume From SPT data, Loading test data, and PDA test

\begin{tabular}{|c|c|c|c|c|}
\hline No & Metode & Titik & $\begin{array}{l}\text { Daya dukung } \\
\text { Realisasi(ton) }\end{array}$ & $\begin{array}{c}\text { Rata- } \\
\text { rata(ton) }\end{array}$ \\
\hline \multirow{4}{*}{1} & \multirow{4}{*}{ PDA test } & BP 1879 & 1355.2 & \multirow{4}{*}{1221.72} \\
\hline & & BP 1401 & 1193.2 & \\
\hline & & BP 1251 & 1273.5 & \\
\hline & & BP 1632 & 1065 & \\
\hline \multirow{4}{*}{2} & \multirow{4}{*}{ Metode Reese \& Onail } & $\mathrm{BH}-1 \mathrm{~A}$ & 1249.65 & \multirow{4}{*}{ 1211.61 } \\
\hline & & BH-2A & 1214.18 & \\
\hline & & BH-3A & 1245.99 & \\
\hline & & BH-4A & 1136.63 & \\
\hline \multirow{4}{*}{3} & \multirow{4}{*}{ Metode Reese \& Wright } & BH-1A & 1032.34 & \multirow{4}{*}{1235.02} \\
\hline & & $\mathrm{BH}-2 \mathrm{~A}$ & 1258.65 & \\
\hline & & BH-3A & 1274.99 & \\
\hline & & $\mathrm{BH}-4 \mathrm{~A}$ & 1374.11 & \\
\hline \multirow{3}{*}{4} & \multirow{3}{*}{ Metode Mazurkiewichz } & $\mathrm{KN}-01$ & 1249 & \multirow{3}{*}{1267.00} \\
\hline & & $\mathrm{KN}-02$ & 1190 & \\
\hline & & $\mathrm{KN}-03$ & 1362 & \\
\hline \multirow{3}{*}{5} & \multirow{3}{*}{ Metode Davisson } & $\mathrm{KN}-01$ & 952,33 & \multirow{3}{*}{850,40} \\
\hline & & $\mathrm{KN}-02$ & 666 & \\
\hline & & $\mathrm{KN}-03$ & 932,87 & \\
\hline
\end{tabular}

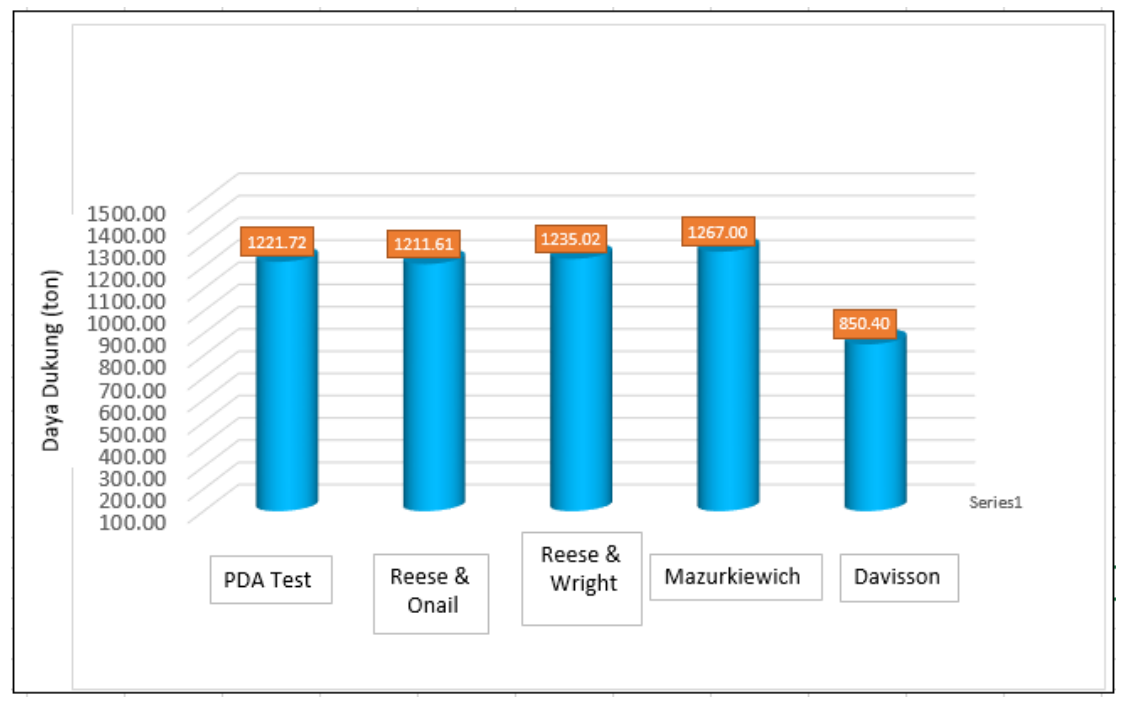

Source: Data in research, 2019

Figure 1. Qull Resume From SPT data, Loading test data, and PDA test

\section{Conclussion}

From the results of research and testing obtained the following results:

1. Ultimit carrying capacity of the N-SPT data calculation using the O'nail \& Reese method is 1211.61 tons and the Reese \& Wright method is 1235.02 tons.

2. Carrying capacity with Interpretation Loading Test using Mazukiewicz Method is 1267.00 tons and Davisson method is 850.40 tons.

3. Carrying capacity of PDA test results is an average of 1221.72 tons. 
4. Comparison of the carrying capacity from manual calculations with plans is the O'nail \& Reese Method is $230.7 \%$, the Reese \& Wright Method is $235.2 \%$, the Marzukiewicz Method is $241.3 \%$, the Davisson Method is $161.9 \%$, and the PDA test of $232.7 \%$ of the carrying capacity of the plan is 525 tons.

\section{References}

Hardiyatmo, H. C. (2014): Analisis dan Perancangan Fondasi I, Gajah Mada University Press, Yogakarta. Hardiyatmo, H. C. (2015): Analisis dan Perancangan Fondasi II, Gajah Mada University Press, Yogakarta. Anonim. (2014) : Perbandingan Analisis Daya Dukung Bored Pile Tunggal Dengan Menggunakan Perhitungan Manual dan Loading Test di Jakarta Selatan. Laporan Tugas Akhir. Universitas Mercubuana.

Sutrisno, Martin. (2015) : Analisa Daya Dukung Pondasi Tiang Pancang Pada Proyek Apartemen Podomoro Golf View Cimanggir. Laporan Tugas Akhir. Universitas Mercubuana. 